\title{
Application of Information Literacy Based on English Ability: Case Study of The Information and Library Science S-1 Study Program Students, Academic Year 2013
}

\author{
Jumino $^{\left.1^{*}\right)}$ \\ ${ }^{1}$ Program Studi S-1 Sastra Inggris, Fakultas Ilmu Budaya, Universitas Diponegoro, \\ Jl. Prof. Soedarto, SH, Tembalang, Semarang. \\ ${ }^{*}$ Korespondensi: juminoya@gmail.com
}

\begin{abstract}
The purpose of this study is to find out how the application of information literacy based on the students' English ability of S1 Library Science Study Program Faculty of Humanities Diponegoro University of Semarang, year 2013. The research method used is descriptive qualitative with case study type. The subject of this research is the students of S1 Library Science Study Program, year 2013, and the object of English proficiency and its application for information literacy. Data collection was done by interview and document study. The informants were chosen by purposive sampling, that is, the students of S1 Library Science Study Program Faculty of Humanities Diponegoro University of Semarang, year 2013 who have got information literacy subject amount of 15 students. The result of the research shows that the students of year 2013 have used English to be literate. They understand their needs, then seek information either from international journals, via internet, or from the library. The use of their information is clear, that is, to support in writing thesis. They can overcome their lack of English language skills.
\end{abstract}

Keywords: English ability; information literacy;; library science; online; year 2013

\section{Introduction.}

Becoming a superior research university in 2020 is a jargon seriously by Diponegoro University. The jargon becomes the vision of the Diponegoro University transmitted to all faculties within the university. One of the faculties is at Diponegoro University is the Faculty of Humanities. Faculty of Humanities also has a vision that matches the vision of Diponegoro University. The vision of the Faculty of Humanities is a leading research faculty in Southeast Asia in 2025 in the field of culture which includes literature, language, history, anthropology, libraries, philosophy, and archives. Universities as higher education institutions are obliged to provide education and guidance to students to be able to perform research activities well and responsible. Good research activity means students are able to search reputable reference sources, while responsible research activities are students know ethics and academic law around the use of information. Therefore it is important for the college to provide the provision of information literacy skills within an integrated and integrated information literacy instruction kit (Paterson and Gamtso, 2016) ${ }^{1}$. Through literacy instruction such information will be foster students' confidence in their information literacy capabilities. Subject has been extensively researched by previous studies, it is stated that there are a positive relationship between self-confidence an individual's literacy ability towards ability of information literacy (Pinto and Fernandez Pascual, 2016). ${ }^{2}$

All teaching and learning activities conducted by students since semester one have been trained to conduct research. The training is summarized in tasks that are given by faculty. In the assigned task, students are invited to observe a natural or social phenomenon, then collect data from the results observation, and make a report of the data obtained. Students are trained and mentored to study and develop the capabilities of the various disciplines covered in the learning curriculum. English is an international language which is one of them functions as a language of science and technology. Many learning references, either in the form of books, journal articles, and documents written in English. It is demanding students, especially students of Diponegoro University's Diponegoro University, Library 
Science S-1 Study Program master English in order to obtain information for absorption and development of the knowledge they learn.

To be able to do research well, a student must have skills in applying information literacy. Moreover in the information age as it is today, information is abundant and easy to obtain. However if the students having been trained become non-critical literates, they can get caught up in information that is not relevant even invalid. To be able to have the skills that must be owned by students in learning, they must have the ability of information literacy. Furthermore, information literacy skills based on students English skills should be applied. How can students understand the science that many references written in English if they do not have the ability to do so. That is why research questions emerge on how the application of information literacy based on English speaking ability especially for the students of SLibrary Science Study Program, Faculty of Humanities Diponegoro University Semarang academic year 2013.

The purpose of this study is to find out how the application of information literacy information based on English proficiency by students of Library Science S-1 Study Program, Faculty of Humanities Diponegoro University of Semarang force 2013. This research is important to do because by knowing ability of English in Information Literacy, it can be used to provide solutions to change the English language teaching program and Literacy information in the curriculum of 2017 - 2021.

The Association of College and Research Libraries (ACRL) provides a characteristic description of a person who has literacy skills information as follows:

1) Determining the required information

2) Accessing information needs effectively and efficiently

3) Evaluate the information and sources it obtains critically.

4) Combining the information it selects into a knowledge base

5) Use information effectively to achieve certain goals

6) Know the economic, legal, and social issues surrounding the use of information, as well as using information ethically and legally. $(2000)^{3}$

Boekhorst $(2003)^{4}$ defines Information Literacy through three concepts, namely: ICT concept: refers to the competence in using ICT to find and disseminate information. Information Resource concept: the competence of finding and using information independently or through the assistance of intermediaries. Information Process concept is the competence to recognize information needs, find, evaluate, use, and disseminate information to obtain and add new knowledge (including ICT and IR concepts). Then UNESCO $(2007)^{5}$ describes that information Literacy directs knowledge of consciousness and needs of one's information, and the ability to identify, discover, evaluate, organize and effectively create, use, communicate information to find solutions to problems encountered. Meanwhile, according to Armstrong (2015) ${ }^{6}$ is "Information literacy involves the knowledge and use of the skills or competencies that together make for effective and appropriate use of information "which the understanding is ability related to knowledge and use of ability or competence together that make the use of information appropriately and effectively. In this research information literacy used in accordance with the theory of Armstrong (2015) mentioned above, because it is related to the ability of the use of information.

According to Bruce, in Pendit $(2013)^{7}$, the thoughts of information literacy among librarians appear simultaneously with the presence of the concept of information society. Literacy of new information appears in the final publication of the report of the American Library Association in 1989, and since then the concept of information literacy began to be widely used. According to Pendit (2013) reviewing the writings of Bruce $(1997)^{8}$, stating that from the table created by Bruce, there are two things agreed upon from the side of the concept and the practical side, namely that information literacy is a matter of using information technology, and that information literacy is a process of applying skills. Then Donaldson (2004) sets limits the skills that must be possessed by students in conducting research in the Current information era, among others:

1. Know what topics to look for, with Focus on the topic (narrow topic / extend the scope); 
2. Understand the significance of the terminology and determine the correct subject headings;

3. Diversify source (use books, magazines, internet sites, etc.);

4. Use Boolean strategy (AND, OR, NOT) on computer search;

5. Critical evaluation of embedded matter; and

6. Catch all sources.

To be able to understand the terminology of the source of information sources that most can be complete from the website, students must be able to understand English well. Zaky (2017) ${ }^{9}$ and May (2017) ${ }^{10}$ states that in English there are four types of skills that students need, namely listening, speaking, reading and writing. The four skills are important to master when they want to learn and use English. In this study the ability to use English because the related reading of the article then the ability to speak English is used in this study only reading, which is associated with comprehension (Reading comprehension).

\section{Methods}

The research method used in this research is qualitative approach. The type of research used is case study. The subject in this study is the students of Library and Information S-1 Study Program, Faculty of Humanities, Diponegoro University Semarang, academic year 2013, and its object is the application of information literacy based on English speaking ability by the students.

Research Questions for Information Literacy use Donaldson's theory $(2004)^{11}$, while the research questions for English ability based on listening, speaking, reading and writing ability. Informants in this study were chosen by purposive sampling, accordingly with the aim of this study, which is the 2013 student who has been and is conducting research for the thesis. The number of informants is 10 students. Data collection is done with interviews and documents derived from student thesis academic year 2013. Informants were selected using purposive sampling, that is the students of Library and Information S-1 Study Program academic year 2013 who had passed Literacy Information Course.

\section{Results}

This research started with interview to informant as many as 10 students of Library and Information S-1 Study Program academic year 2013 about information literacy consisting of research activity: 1) Whether the informants know the information needed; 2) Understand the significance of the terminology and determine the correct subject headings; 3) Use sources diversity (use books, magazines, internet sites, etc.); 4) Use the Boolean logic (AND, OR, NOT) on computer search; 5) Apply critical evaluation of embedded matter; 6) Call all source.

To be able to understand the terminology of most information sources from the website, the students must be able to understand English well first. Therefore, a research question is needed about the ability to use English, namely listening, speaking, reading and writing ability.

From interviews to research questions on information literacy research question about information knowledge needed, 7 informants answer that they know the source of information needed, because they have chosen the topic research, and that 3 informants say that they know what they need because research topics they have determined since following the seminar subject in semester 7 . All informants have been aware of the information they need first.

About the understanding of the significance of terminology asked about the searching method information, 1 student applies through the name of the researcher; 5 informants use keyword plus way search using Boolean logic and key word of author name; 1 student utilizes a special download site (scihub.cc and libgen.io). Thus most informants use the key words, and upon answers to further questions why use them, because the result is more appropriate, if the subject heading is correct. So mostly the informants understand the importance of information terminology or the keywords being searched. Then on the question of the importance of understanding the terminology of the topic sought, 8 informants state 
that terminology is indispensable because of order in accordance with what they are looking for, and 2 others state that terminology at the beginning the search is still a bit confused, so it is less in line with the results sought; but after consultation with the supervisor lecturer becomes clear. Thus all informants state that terminology is very important to get the results accordingly with their needs.

On how to find information, 7 out of 10 informants search for information through the internet, whether through social media, browsing through the web, and the other 3 informants also ask to his friends and search the information to library. Thus they all seek information via the internet and some use printed books. This is understandable because they all belong to Digital Native Generation, the generation that has forged the use of computers since early age, thus affecting their way of thinking to acquire and processing information. This generation is different from the previous generation of Digital Immigrant. (Pendit, 2013).

Next, from the question about what sources are used in finding information required, 6 out of 10 informants use the journal, either printed or internet, and others use printed books. Then from the questions about the source used are deepened with questions about how to information search, 7 out of 10 informants seek information through internet, both through social media, browsing through the web, and the 3 informants use the library search. With most informants looking for information through the internet, then the question is sharpened with search engines. what is used, it is obtained all informants answers look for information through Google Chrome search engine. Therefore, more than half of the informants have diversified their sources of information and information search advice.

Informants answers to the fourth information literacy indicator on strategy Boolean usage, five informants use keywords plus how to search using Boolean Logic and author name keywords; one informant utilize the special downloader sites (sci-hub.cc and libgen.io). Thus most informants have already used Boolean Logic. This is understandable because they are all have got a lecture Information Retrieval teaching how to find information quickly and precisely.

Answers on how to evaluate the material retrieved. Of the 10 informants, 6 informants do so by looking at the content of the information whether it is appropriate with what is needed or not, 1 informant sees newness of the information, and 3 informants look at the relevance of the information content. Therefore most informants have evaluated the content of the information they use.

Then the question is developed whether they have cited all sources, the answer is that 7 informants use the source information which are diverse, some search from the library, then if not found out of internet, some are straight from the internet. Related search via the internet, seven informants state they use an international journal portal and only 2 informants are search directly from Google, and 1 informant use lecturer blog. So informants have cited information from various sources, both from libraries and from the internet, including from the e-Journal portal and lecturers blog.

To be able to understand the terminology of most information sources accessed from the website, the students must be able to understand English well. The ability to understand English studied is based on their reading comprehension ability because it is related to understanding of the article. Ability to read is then applied to several research questions, namely:

1. Frequency informant searching information in English;

2. What English source of information to use;

3. Understanding the content of the reading;

4. Things done to master English related to the information search over the internet;

5. Percentage of English-language articles used in the writing of scientific papers;

6. Difficulties encountered when searching information in English;

7. Obstacles experienced in the search for information in English; and

8. How to overcome the difficulties of understanding English-language the articles.

\section{Discussion}


The results of interviews with informants are then analyzed. The results of the analysis are as follows:

\subsection{Search information in English}

Based on the answers of question, "How often do you search inside English information?", it is known that only 4 informants use English, 3 informants sometimes use, 2 informants rarely, and 1 informant never use it. Thus almost half the informants often use language-based English articles, and that is partly only occasionally, and only one informant says never. Based on the result of triangulation, it is known that the lecturer does exist require the use of references from articles in international journals, and other lecturers do not require it. It can therefore be understood there are some students who never use an English articles.

\subsection{Sources of information in English}

Based on the answers of question "What English information sources are used?", it is known that most informants answer that they used the source of information of e-Journal, obtained directly from Google scholar, and only one informant uses the source information from lecturer blog. This is understandable because of the triangulation results some lecturers require the students to use international journals, although some do not. Besides, the source of information about Library Science and information in the book format still scarce. Therefore almost all informants use English-speaking sources from the internet, both from international journals, and from Google or Google Scholar.

\subsection{Understanding the content of the reading}

Based on the answers of question "Do you understand the contents of the reading?", it is known that 8 Informants understand the content of the reading, and 1 informant understands a little and 1 informant has difficulty in understanding, because language is difficult and the terms are difficult to find in the ordinary dictionary. Thus most informants understand the content of their reading.

\subsection{Search information via internet}

Based on the results of interviews with informants, the things the informants did for mastery of English in translating, it is found that 4 informants use of printed English dictionary to search for important vocabulary as they are not happy using an online dictionary, 3 informants use online dictionary, 2 informants enrich themselves by listening to music and viewing movies, and 1 informant by asking friend. Thus most informants ( 7 informants) use a good online dictionary or printed dictionary, the other in their own way to the taste of the young informants. Thus, there are some informants who borrow printed dictionary from libraries as well. This is understandable because with the online dictionary sometimes the translation is still unclear.

\subsection{English articles used in the writing of scientific papers}

In answering the question of bow often informants use English language articles, only 4 informants often use English, 4 informants sometimes, 2 informants rarely, and 1 informant never uses. 4 informants use more than 50\% English articles, and 4 informants less than 50\% English articles, 1 informant around $20 \%$ rarely uses, and 1 other never uses. It is related to their ability and deep mastery of the English language, there is a good score in the course Integrated Skills with grades B and A, but others get $\mathrm{D}$, and after improvement they get $\mathrm{C}$.

\subsection{Difficulties encountered when searching information in English}


Based on the Informants in answering question how to overcome difficulties in understanding the English-language articles, It is that To overcome language difficulties, 5 informants use Google translate / dictionary online, 1 informant uses Google translate first, then synchronized, and 5 informants use a printed dictionary. So half the informants use Google translate and the remaining half using a printed dictionary. This is understandable because to use an online dictionary, there must be connection with the internet. In fact, the internet in the faculty is often slow in its course, its small Wi-Fi signal. Therefore if they are pressed when they use a printed dictionary. So, many informants tend to borrow printed dictionary from library.

\subsection{Obstacles experienced in the search for information in English}

Based on the question of what obstacles are experienced in the search for information in English, it is known that the barriers are experienced by informants in looking for information in English. 4 informants have internal barriers interpretation the reading, because of difficulty in understanding its meaning. Then 4 informants have trouble determining keywords, and 2 informants who get results do not match with the required. Thus all informants get deep search barriers information, although in the end they can handle it. If viewed from the courses offered, however, they have got Information Literacy and Information Retrieval. And from the observation of documents, all of them already passed with good grades.

\subsection{Overcoming difficulties to understand English-language articles}

From the question to the informants on how to overcome the difficulties in understanding English-language articles, it is known that to overcome language difficulties, 5 informants use Google translate / online dictionary, 1 informant uses Google translate first, then synchronized, and 4 informants use printed dictionary. Thus it can be concluded that all informants use dictionaries in both printed dictionaries and online dictionaries. Only 1 informant after using the online dictionary is then synchronizes the result

\section{Conclusion}

Based on analysis of research results on Application of Information Literacy based on English Ability: Case Study of Student of Library and Information S-1 Study Program, Faculty of Humanities Diponegoro University academic year 2013, it can be conclude that:

1. Most informants understand the importance of terminology of information or keywords sought.

2. Most informants look for information via the internet, either through social media, browsing through the web, however some still use seek information from printed books.

3. About the source of information used, more than half of the informants have diversify sources of information as well as suggestions for information-seeking means.

4. About the use of Boolean strategies, most informants are already use it.

5. In the use of English in the search for information, half informants use the English language.

6. Most informants understand the content of their reading.

7. Most informants use dictionaries both online and printed dictionaries.

8. Barriers experienced by informants in finding information in English relate to the obstacles in interpreting the reading, because they understand the meaning poorly.

9. In general to overcome the difficulties in understanding English-language articles, all informants use dictionaries both in online and printed dictionaries.

\section{References}

\footnotetext{
${ }^{1}$ Paterson, Susanne F, and Carolyn White Gamtso. 2016. "Information Literacy Instruction in an English Capstone Course: A Study of Student Confidence, Perception, and Practice."
} 
2 Pinto, Maria, Rosaura Fernandez-Pascual, and Susana Puertas. 2016. "Undergraduates Information Literacy Competency: A Pilot Study of Assessment Tools Based on a Latent Trait Model." Library \& Information Science Research 38 (2): 180-189. doi:10.1016/j.lisr.2016.05.004.

3 Association of College and Research Libraries. (2000). "Information Literacy Competency". (http://www.ala.org/acrl/standards/informationliteracycompeteny)

${ }^{4}$ Boekhorst, A. K. 2003. "Becoming information literate in the Netherlands". Library Review, Vol. 52.

${ }^{5}$ UNESCO, 2007. "Information for All Programmes: Understanding Information Literacy." A Primer. Paris: UNESCO.

${ }^{6}$ Armstrong, D; Boden, D; Town, S.; et.al. (2015). "CILIP Defines Information Literacy for the UK. [http://eprints.rclis.org/7459/], accessed 10 Nov. 2017.

${ }^{7}$ Pendit, PL, 2013. "Digital Native, Literasi Informasi dan Media Digital : Sisi pandang kepustakawanan" . Paper presented in Seminar and Workshop Paradigm Changes on Library Digital Natives Universitas - Satya Wacana Christian University Salatiga 17 - 18 January 2013. http://repository.uksw.edu/handle/123456789/4721.

${ }^{8}$ Bruce, C. 1997. The Seven Faces of Information Literacy, Adelaide : Auslib Press.

9 Zaky. (2017). "4 Keterampilan Dasar Bahasa Inggris (Efektif untuk Pemula)." http://azbahasainggris.com/keterampilan-dasar-bahasa-inggris. [ 12 Nov.2017].

10 May, Yona. (2017). "4 Skills (Kemampuan) dalam Bahasa Inggris dan Cara Menguasainya". http://www.ilmubahasainggris.com/4-skills-penting-saat-belajar-bahasa-dalam-bahasainggrisyang-wajib-kita-ketahui/. Accessed 12 March 2017.

${ }^{11}$ Donaldson, Christy A. 2004. "Information Literacy and the McKinsey Model: The McKinsey Strategic Problem-Solving Model Adapted to Teach Information Literacy to Graduate Business Students". Library Philosophy and Practice, Vol. 6. 